\title{
Neurofilament Protein Synthesis in DRG Neurons Decreases More After Peripheral Axotomy than After Central Axotomy
}

\author{
Sharon G. Greenberga and Raymond J. Lasek \\ Bio-archtectonics Center, Case Western Reserve University Medical School, Cleveland, Ohio 44106
}

Cytoskeletal protein synthesis was studied in DRG neurons after transecting either their peripheral or their central branch axons. Specifically, the axons were transected 5-10 $\mathrm{mm}$ from the lumbar-5 ganglion on one side of the animal; the DRGs from the transected side and contralateral control side were labeled with radiolabeled amino acids in vitro; radiolabeled proteins were separated by 2-dimensional (2D) PAGE; and the amounts of radiolabel in certain proteins of the experimental and control ganglia were quantified and compared. We focused on the neurofilament proteins because they are neuron-specific. If either the peripheral or central axons were cut, the amounts of radiolabeled neurofilament protein synthesized by the DRG neurons decreased between 1 and $10 \mathrm{~d}$ after transection. Neurofilament protein labeling decreased more after transection of the peripheral axons than after transection of the central axons. In contrast to axonal transections, sham operations or heat shock did not decrease the radiolabeling of the neurofilament proteins, and these procedures also affected the labeling of actin, tubulin, and the heat-shock proteins differently from transection. These results and others indicate that axonal transection leads to specific changes in the synthesis of cytoskeletal proteins of DRG neurons, and that these changes differ from those produced by stress to the animal or ganglia. Studies of the changes in neurofilament protein synthesis from 1 to $40 \mathrm{~d}$ after axonal transection indicate that the amounts of radiolabeled neurofilament protein synthesis were decreased during axonal elongation, but that they returned toward control levels when the axons reached cells that stopped elongation. These observations support the proposal that neurofilament protein synthesis is critically regulated by retrogradely transported materials from the axon terminals (Hoffman et al. 1985, 1987) and they indicate that the amounts of these factors transported in the peripheral axons are normally greater than those in the central axons.

Transection of a mature, nonelongating axon leads to alterations of the steady state of cytoskeletal protein synthesis in the neuron (Heacock and Agranoff, 1976; Giulian et al., 1980; Hall, 1982; Neumann et al., 1983; Quesada et al., 1986; Hoffman et al., 1987). After the axon is cut, it achieves a new steady state, and

Received June 18, 1987; revised Oct. 15, 1987; accepted Oct. 20, 1987.

We wish to thank Shirley Rickets and Diane Filsinger for their excellent technical assistance. This work was supported by a NIH training grant to S.G.G. and grants to R.J.L.

Correspondence should be addressed to Raymond J. Lasek at the above address.

a Present address: Department of Pathology, Albert Einstein College of Medicine. 1300 Morris Park Avenue, Bronx, NY 10461.

Copyright (C) 1988 Society for Neuroscience $0270-6474 / 88 / 051739-08 \$ 02.00 / 0$ while it is actively elongating, tubulin and actin synthesis are generally increased, whereas neurofilament protein synthesis is decreased. When the elongating axon contacts a matching target cell and stops elongating, the amount of neurofilament mRNA and axonally transported neurofilament protein return to the normal level of the intact neuron (Hoffman et al., 1985, 1987). These observations and others indicate that neurofilament protein synthesis is critically controlled by factors that are retrogradely transported from the axon tip and that the amount of these factors that reach the cell body depends on the state of the axon tip-specifically, whether the axon has been stopped from elongating by contacting a target cell.

DRG cells have a single axon that bifurcates into two branches-the central branch projects through the dorsal root and terminates on neurons in the spinal cord and brain, and the peripheral branch projects through the peripheral nerves and terminates on sensory receptors in the skin or muscle. Because of this arrangement, either the central or peripheral axon can be selectively cut and the effects of removing different parts of the axonal arbor can be studied. The DRG cells respond differently to transection of their peripheral and central axons (reviewed in Cragg, 1970; Lieberman, 1971). Transection of the peripheral branch stimulates dramatic cytological changes (chromatolysis) in the DRG cell body, whereas transection of the central branch produces little or no effect. Biochemical analyses show that the synthesis of certain proteins changes in response to transection of the peripheral axon, but not to transection of the central axon (Perry and Wilson, 1981; Hall, 1982; Perry et al., 1983). Analyses of cytoskeletal protein transport from the cell body show that the neurofilament: tubulin ratio in slow transport decreased after transection of the peripheral branch, and that it was unchanged after transection of the central branch (Oblinger and Lasek, 1985, 1988).

To further explore the mechanisms that regulate the amount of cytoskeletal protein synthesis in neurons, we have analyzed the incorporation of amino acids into cytoskeletal proteins of the DKG neurons after transection of their peripheral and central branch axons. The neurofilament proteins are of particular interest because these protcins are spccific for the nerve cells of the DRG (Shaw et al., 1981). Furthermore, all of the neurofilaments are transported into the axons (Lasek et al., 1983). Thus, the mechanisms that regulate the amount of neurofilament protein synthesis directly affect the properties of the axon.

\section{Materials and Methods}

Animal operations. Sprague-Dawley male rats (200-300 gm) were anesthetized with Chloropent $(3 \mathrm{ml} / \mathrm{kg})$. To cut the peripheral axon of the L5 DRG, the L5 spinal nerve was exposed after removing the transverse process of the $\mathbf{L} 6$ vertebra, and then crushed with \#5 Dumont forceps 

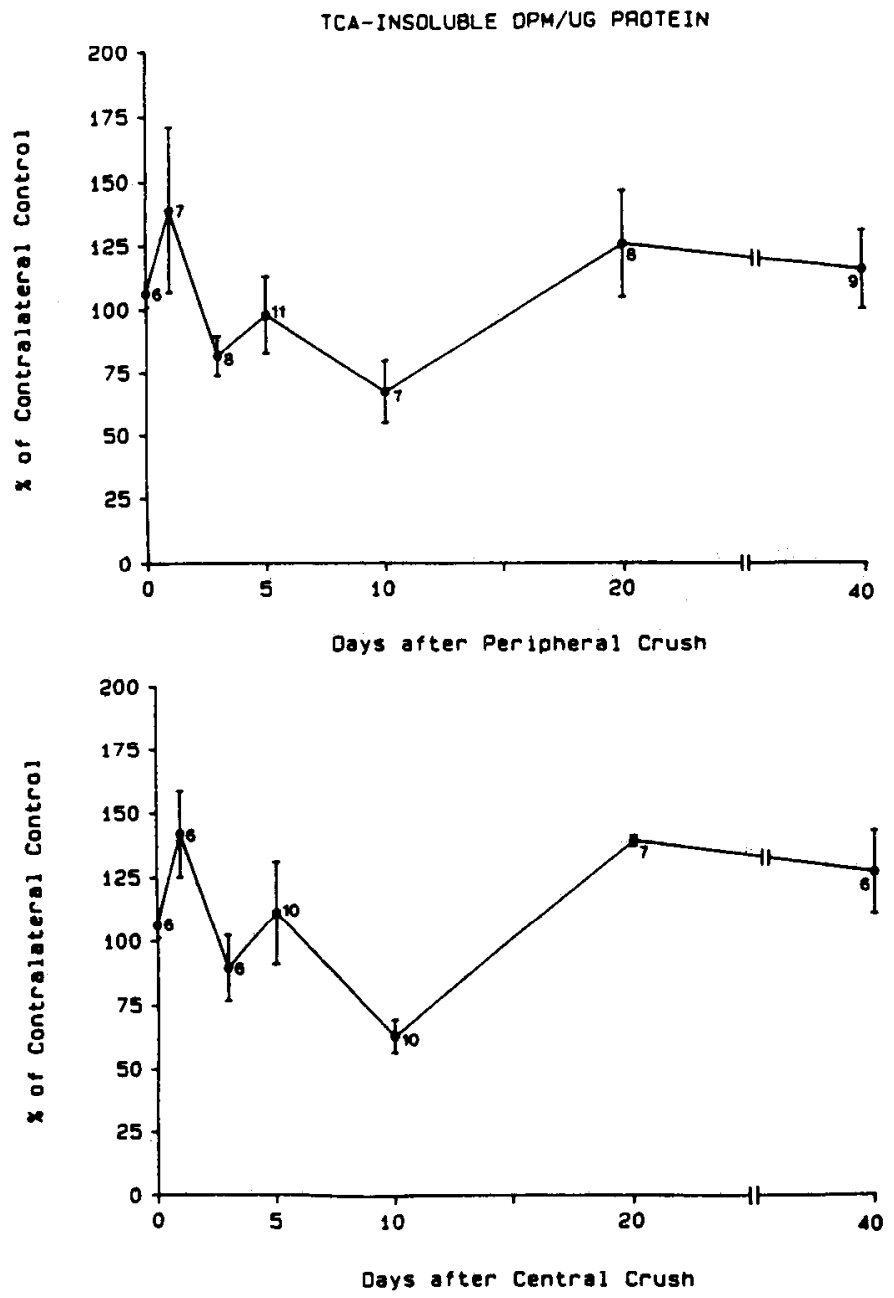

Figure 1. Time course of alterations in the incorporation of radioactivity into total DRG proteins. At the indicated time intervals after peripheral or central crushes, DRGs were labeled in vitro with ${ }^{35} \mathrm{~S}$ methionine for $1 \mathrm{hr}$ and then homogenized. The total radioactive incorporation into DRG proteins represents the amount of TCA-insoluble $\mathrm{dpm} / \mu \mathrm{g}$ protein. Experimental samples were evaluated as a percentage of their contralateral control. Numbers indicate total animals analyzed at each time point.

at a distance of 5-10 $\mathrm{mm}$ from the ganglion, where the $\mathrm{L} 5$ and $\mathrm{L} 4$ spinal nerves join. To cut the central axon, the $\mathrm{L} 5$ dorsal root was exposed by a laminectomy at the level of L4, the dura mater was cut, and the root crushed with \#5 Dumont forceps at a distance of $5-10 \mathrm{~mm}$ from the ganglion. Previous studies have indicated that this method completely transects all axons in the nerve (Wujek and Lasek, 1983). After the nerves were crushed, the operated area was flushed with saline $(0.9 \mathrm{M}$ sodium chloride) and damaged muscle was removed. The overlying muscle was sutured and the skin incision closed with wound clips. Sham operations consisted of similar surgical procedures, except that the peripheral or central process was not crushed.

The distance between the site of the dorsal root crush and the spinal cord was $2.0-3.3 \mathrm{~cm}(n-16$ animals). Peripheral axons innervate sensory targets in the lower leg (approximately $8.5-11 \mathrm{~cm}$ from the crush site), as well as in the foot (12-15 cm from the crush site). On the basis of these distances, as well as on known regeneration rates and the delay of axonal outgrowth (Wujek and Lasek, 1983), we estimated that the central axons would reach the spinal cord entry zone 10-15 d following transection, whereas peripheral axons would begin to contact their sensory targets 21-35 d following transection. In addition, we used the pinch test to determine when peripheral reflexes reappeared, and our results were consistent with the values determined from regeneration rates of peripheral axons. The pinch test demonstrated that sensory innervation of the foot was present in some animals at $40 \mathrm{~d}$, but not $20 \mathrm{~d}$, following transection of peripheral axons.

Preparation of labeled DRG proteins. Proteins in the L5 DRG were labeled in vitro. Animals were anesthetized and, after exposing the L5 DRG, they were decapitated. The right and left (operated and contralateral control) L5 DRG were removed, washed in $0.9 \% \mathrm{NaCl}$, and the remaining connective sheath and attached nerves removed. Samples were incubated in minimal essential medium (MEM; Gibco) without methionine for $15 \mathrm{~min}$ at $37^{\circ} \mathrm{C}, 5 \%$ carbon dioxide. The media was replaced with prewarmed MEM containing $1 \mathrm{mCi} / \mathrm{ml}$ of ${ }^{35} \mathrm{~S}$-methionine and incubated for $1 \mathrm{hr}$. Samples were washed with cold MEM, homogenized in $50 \mathrm{~mm}$ sodium phosphate buffer, $\mathrm{pH} 8.0$, containing $1 \%$ SDS, and clarified by centrifugation at $1000 \mathrm{rpm}$ (Sorvall). The supernatant was used for further analysis.

Determination of TCA-insoluble radioactivity in DRG proteins. Trichloroacetic acid (TCA)-insoluble radioactivity was determined by aliquoting samples onto $3 \mathrm{~mm}$ Whatman filter paper and precipitating the protein in cold $10 \%$ TCA for $30 \mathrm{~min}$, followed by two $15 \mathrm{~min}$ washes in 5\% TCA and 3 ethanol washes. The amount of TCA-insoluble radioactivity on the dried filters was determined after adding Formula 963 (New England Nuclear). TCA-insoluble radioactivity was corrected for radioactive decay. Protein levels were determined using the fluorescamine assay (Bohlem et al., 1973). Samples were in the linear range for this assay $(5-100 \mu \mathrm{g})$. TC $\Lambda$ and protein assays were performed in duplicate.

Two-dimensional gel electrophoresis. Two-dimensional gel electrophoresis was performed as described by O'Farrell (1975). Prior to isoelectric focusing, (IEF), samples were mixed with lysis buffer ( $9 \mathrm{M}$ urea, $8 \%$ Triton X-100, $5 \%$ beta-mercaptoethanol, and $2 \%$ ampholines consisting of $1.6 \%$ at $\mathrm{pH} 5-7$ and $0.4 \%$ at $\mathrm{pH} \mathrm{3-10;} \mathrm{LKB} \mathrm{Instruments)}$ After IEF for $6000 \mathrm{~V}-\mathrm{hr}$, the IEF gels were placed on a $7.5 \%$ SDSacrylamide gel with a $4 \%$ stacking gel. Second-dimension gel electrophoresis was performed at $8 \mathrm{~W} / \mathrm{gel}$. The electrophoresis buffer consisted of $0.05 \mathrm{M}$ Tris- $\mathrm{HCl}, 0.38 \mathrm{M}$ glycine, $0.1 \%$ SDS, pH 8.3. Gels were stained with 1\% Sorva blue. After destaining, the gels were subjected to fluorography by dehydration with dimethyl sulfoxide (DMSO) and impregnated with 2,5-diphenyl sulfoxide (PPO) (Bonner and Laskey, 1974; Laskey and Mills, 1975). The gels were vacuum-dried onto dialysis men. brane and fluorographs were made using XAR-5 film (Kodak) at $-70^{\circ} \mathrm{C}$.

Quantitation of labeled proteins. The identity of the labeled cytoskeletal proteins in fluorographs was determined by comigration with unlabeled actin or tubulin, or by reaction with neurofilament-specific antibodies (Greenberg, 1986). Fluorograph duplicates were used to locate labeled proteins. Protein spots were cut from the gel and solubilized by incubation in $0.75 \mathrm{ml}$ of $30 \%$ hydrogen peroxide at $60^{\circ} \mathrm{C}$ for $48-72$ $\mathrm{h}$. The radioactivity was determined by liquid-scintillation counting in Formula 963. The average background from 4 spots on the gel was subtracted and degradations per minute were corrected for isotope decay.

With the exception of the $200 \mathrm{kDa}$ neurofilament protein, the cytoskeletal proteins in control samples generally contained sufficient radioactivity to be detected by this procedure. To accurately assess alterations in the radioactive incorporation in cytoskeletal proteins in the experimental situations, labeled proteins that were not at least two times above background levels in control conditions were not used for analysis. The amount of radioactivity present in the $70 \mathrm{kDa}$ heat-shock protein (HSP 70) was not generally above background levels in control situations. When levels of radioactivity were not consistently above background levels in control or experimental conditions, paired comparisons of HSP 70 indicated that the levels of radioactivity approached nondetectable levels.

\section{Results}

\section{Incorporation of radioactivity into total $D R G$ proteins}

The effects of transection of the peripheral and central DRG axons on the incorporation of radioactivity into total DRG proteins (TCA-insoluble dpm/ $\mu$ g protein) are illustrated in Figure 1. Transection of either the central or peripheral axons produced similar overall changes in the radiolabeling of total DRG proteins. Notably, the levels of radiolabeled protein increased $1 \mathrm{~d}$ after transection and then decreased between 1 and $10 \mathrm{~d}$ to less than the values of the contralateral control ganglia. After 
Table 1. Effect of crushes, sham operations, or heat shock on the levels of radioactive incorporation into specific proteins (paired comparisons)

A. 5 Days after crush

\begin{tabular}{|c|c|c|c|c|c|c|c|}
\hline & Contralateral control & $(\%)(\mathrm{SEM})^{a}$ & & Contralateral control & $(\%)(\mathrm{SEM})^{a}$ & & $\begin{array}{l}\text { Contralateral control } \\
\text { (\%) (SEM) }\end{array}$ \\
\hline & $\begin{array}{l}\text { Peripheral } \\
n=6\end{array}$ & $\begin{array}{l}\text { Control } \\
n=6\end{array}$ & & $\begin{array}{l}\text { Peripheral } \\
n=5\end{array}$ & $\begin{array}{l}\text { Control } \\
n=4\end{array}$ & & $n=5$ \\
\hline NF68 & $22(5) \quad p<0.005$ & $50(10) p<0.01$ & NF68 & $125(8) \quad p<0.025$ & $115(15)$ & NF68 & $79(24)$ \\
\hline NF145 & $18(5) \quad p<0.005$ & $38(9) \quad p<0.025$ & NF145 & $126(20)$ & $120(19)$ & $\mathrm{NF} 145^{\prime}$ & $70(19)$ \\
\hline Actin & 146 (11) $p<0.005$ & $121(8) \quad p<0.025$ & Actin & $104(12)$ & $100(7)$ & Actin & $p<0.025$ \\
\hline Tubulin & $152(14) p<0.025$ & $111(4)$ & Tubulin & $108(4)$ & $98(5)$ & Tubulin & $p<0.025$ \\
\hline HSP 70 & $0^{\prime \prime}$ & 0 & HSP 70 & 0 & 0 & HSP 70 & $3600(990) p<0.005$ \\
\hline $1(70 \mathrm{kDa})$ & $91(14)$ & $104(10)$ & $1(70 \mathrm{kDa})$ & $93(5)$ & $139(21)$ & $1(70 \mathrm{kDa})$ & $88(10)$ \\
\hline $2(43 \mathrm{kDa})$ & $150(23)$ & $125(10 y$ & $2(43 \mathrm{kDa})$ & $91(23)$ & $108(7)$ & $2(43 \mathrm{kDa})^{\gamma}$ & $110(32)$ \\
\hline $\begin{array}{l}\text { Total radio- } \\
\text { active in- } \\
\text { corporation }^{b}\end{array}$ & $94(12)^{g}$ & $112(19)^{g}$ & $\begin{array}{l}\text { Total radio- } \\
\text { active in- } \\
\text { corporation }\end{array}$ & $91(12)$ & $87(12)$ & $\begin{array}{l}\text { Total radio- } \\
\text { active in- } \\
\text { corporation }\end{array}$ & $71(19)$ \\
\hline
\end{tabular}

a Statistical analysis for paired comparisons were made using the Student's paired $t$ test. Significant differences of $p<0.05$ are indicated.

${ }^{b}$ Total radioactive incorporation is the total TCA-insoluble dpm $/ \mu \mathrm{g}$ of total protein.

$c n=$ Number of animals used in the analysis, unless otherwise indicated.

${ }^{d} 0$ indicates that the amount of radioactivity present in these proteins was not sufficiently greater than background levels to be analyzed by paired comparisons.

$n=4$.

$\varsigma^{\prime}=5$.

$s_{n}=10$.

$10 \mathrm{~d}$, the levels of radiolabeling increased. Many different factors can contribute to the overall incorporation of radioactivity into DRG proteins. For example, these changes may be due to changes in the general synthetic activity of DRG cells, the synthesis of specific proteins, and the uptake of radioactive amino acids. To selectively study changes in the synthesis of specific proteins, we analyzed the relative levels of radioactive labeling of individual proteins following crushes of the peripheral or central process of the DRG.

\section{Effects on the radiolabeling of individual proteins}

Figure $2 A$ illustrates fluorographs of newly synthesized DRG proteins $5 \mathrm{~d}$ after transection of either peripheral or central axons. The fluorographs suggest that, after peripheral axotomy, the relative amount of radiolabeled neurofilament protein decreased, and quantitative analyses confirmed that NF68 and NF145 decreased to 22 and $18 \%$ of the contralateral control values (Table 1A). By contrast with the decrease in neurofilament protein labeling after peripheral transection, the amount of radiolabeled actin and tubulin increased to 146 and $152 \%$ of the contralateral control values, respectively. None of the other heavily labeled proteins, such as proteins 1 and 2, showed statistically significant changes in response to peripheral axotomy.

At $5 \mathrm{~d}$ after central axotomy, NF68 and NF145 decreased to 50 and $38 \%$ of the contralateral control values, radiolabeled actin increased to $121 \%$ of the contralateral control values, and the amount of radiolabeled tubulin was unchanged from control values. These findings indicate that, while transection of central axons affects synthesis of neurofilament proteins and actin, the magnitude of these changes is less than that observed after transection of peripheral axons.

To determine whether the surgical procedures affected the radiolabeling of cytoskeletal proteins, the radiolabeling of DRG proteins was evaluated in sham-operated animals in which the nerves were exposed but the axons were not transected. Fluo- rographs in Figure $2 B$ suggest that any changes after sham operation were much less than those after axonal transection, and quantitative analysis (Table 1B) indicated that the radiolabeling of actin and tubulin were unaffected by the sham operations. The radiolabeling of NF68 and NF145 was increased to between 115 and $126 \%$ of the contralateral control values, and the difference between radiolabeling of NF68 in the peripheral, shamoperated and contralateral control ganglia was statistically significant $(p<0.025$ ) by Student's $t$ test. These findings indicate that the surgical procedure had relatively little effect on radiolabeling of the cytoskeletal proteins. Moreover, the effect of the sham operation on neurofilament labeling was opposite to that of axonal transection.

\section{Generalized stress response of DRG cells}

To further examine the response of DRG cells to stress, the ganglia were subjected to heat shock. In general, heat shock results in a specific increase in the synthesis of heat-shock proteins, and a decrease in the synthesis of many other cellular proteins (reviewed in Schlesinger et al., 1982). Figure $2 C$ shows that, after heat-treating ganglia at $42^{\circ} \mathrm{C}$ for $15 \mathrm{~min}$, the amount of the radiolabeled $70 \mathrm{kDa}$ protein (HSP 70) increased to $3600 \%$ of the contralateral control values (Table 1C). By contrast with the heavy labeling of HSP 70 after heat treatment, neither the axon transection nor the sham operation increased the radiolabeling of HSP 70 (Table 1A, B). The effects of heat shock on cytoskeletal protein labeling were also different from those of the sham operation and axotomy (Table 1A-C). After heat shock the radiolabeling of actin and tubulin decreased, and the amount of radiolabeled neurofilament protein was not significantly different from the levels of the control preparations. This indicates that the effects of axonal transection on the synthesis of cytoskeletal proteins and HSP 70 differ from those of both sham operations and heat shock. On this basis, we propose that the response of the DRG cell to axotomy is specific and that it differs from the response to stress. 


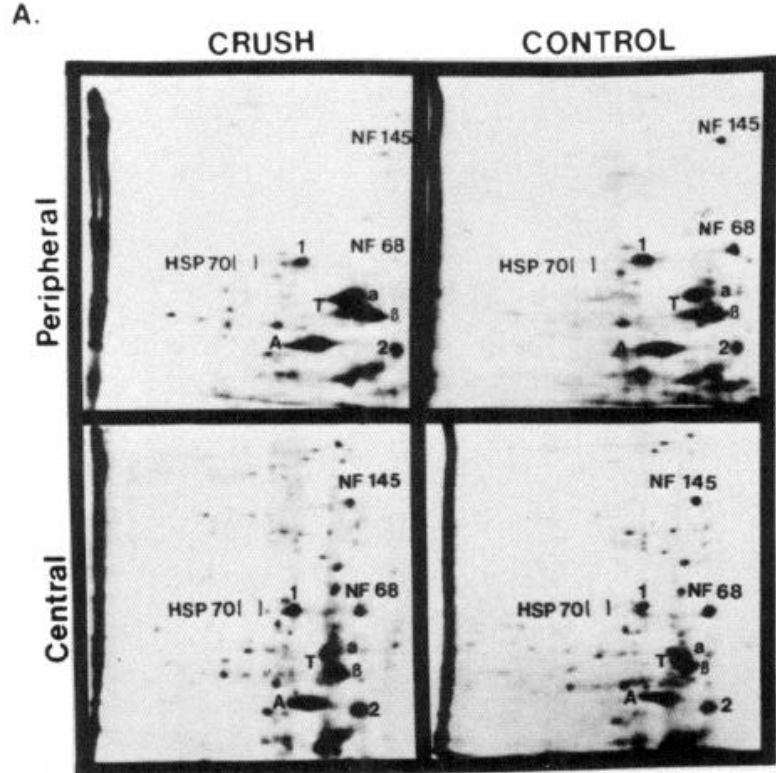

B.

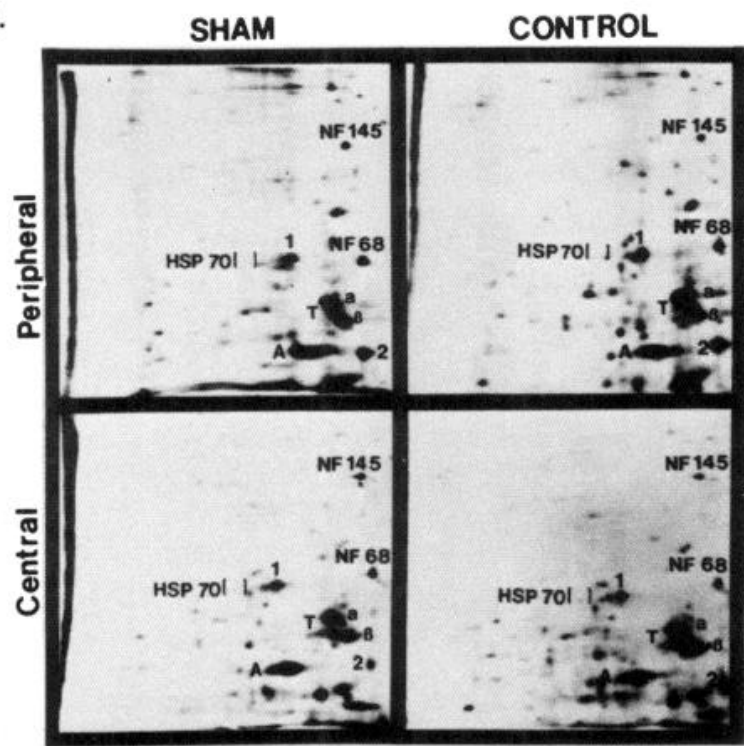

C.

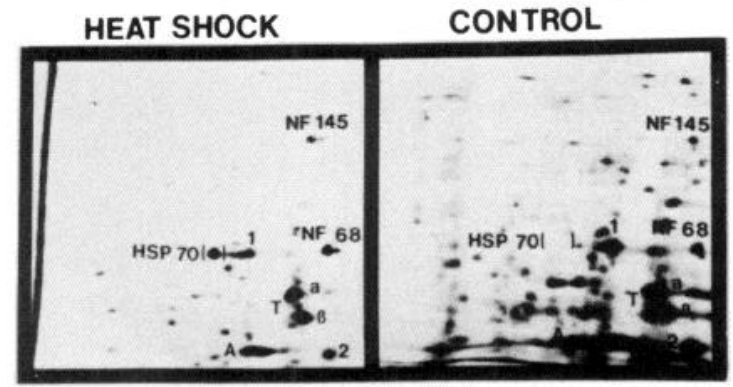

Figure 2. Effect of sham operations or heat shock on the levels of radiolabeled DRG proteins. Five days after peripheral or central crush $(A)$, sham operations $(B)$, or after a 15 min heat treatment at $42^{\circ} \mathrm{C}(C)$ DRGs were labeled in vitro with ${ }^{35} \mathrm{~S}$-methionine for $1 \mathrm{hr}$ and analyzed by $2 \mathrm{D}$ gel electrophoresis and fluorography. Contralateral samples were analyzed simultaneously with experimental samples. These fluorographs represent samples in which equal amounts of total radioactivity were analyzed. The cytoskeletal proteins actin $(A)$, tubulin $(T)$, and the 68 and $145 \mathrm{kDa}$ neurofilament proteins (NF68, NF145), as well as a 70 $\mathrm{kDa}$ protein $(I)$, and a $43 \mathrm{kDa}$ protein (2), are indicated. A large decrease in NF68 and NF145 is clearly observable following a peripheral crush $(A)$.

\section{Time course of cytoskeletal protein synthesis changes}

To examine the relationship of changes in cytoskeletal protein synthesis during the elongation and termination phase of central and peripheral axon regeneration, we quantified the amount of radiolabeled amino acid that was incorporated into cytoskeletal proteins of DRG cells when the peripheral axons reinnervated their sensory targets in the leg or foot (21-35 d after transection) and when the central axons formed axoglial terminals on astrocytes at the dorsal root of the spinal cord (10-15 $\mathrm{d}$ after transection). (For further details, see Materials and Methods.) Figure 3 shows fluorographs of radiolabeling patterns from DRG cells $1-40 \mathrm{~d}$ after transection of either the peripheral or central axons. Quantitation of the radiolabeled proteins shows that the amount of incorporation into NF68 and NF145 decreased markedly between 1 and $5 \mathrm{~d}$ after the central or peripheral axons were transected, and continued to decrease between 5 and $10 \mathrm{~d}$ (Fig. 4). Neurofilament protein labeling in the DRG neurons returned to control levels sooner (between 10 and $20 \mathrm{~d}$ ) after the transection of the central axons than after the transection of the peripheral axons (at $40 \mathrm{~d}$, the amount of radiolabeled neurofilament protein had not reached control levels).

Figure 5 shows the effects of axon transection on actin and tubulin synthesis following the transection of either peripheral or central axons. When the peripheral axons were cut, the amounts of radiolabeled actin and tubulin in the experimental DRG were greater than those of the contralateral control ganglia between 1 and $5 \mathrm{~d}$ after transection; then, between 5 and $10 \mathrm{~d}$, the amounts of radiolabeled actin decreased and approached those of the contralateral control ganglia. After central transection, actin radiolabeling increased between 1 and $10 \mathrm{~d}$, but tubulin was essentially unaffected. These observations indicate that the effects of transection on actin and tubulin are opposite to those on the neurofilament proteins. As with the effects on neurofilament protein synthesis, peripheral transection had more of an effect on actin and tubulin synthesis than did central transection.

\section{Discussion}

\section{Cutting either the central or peripheral axon affects} cytoskeletal protein synthesis in DRG neurons

DRG neurons respond differently to axotomy of their central axons than to axotomy of their peripheral axons. For example, if the peripheral axon of the DRG neuron is cut, the cell body undergoes the typical changes associated with chromatolysis, but if the central axon is cut, the changes in the cell body are much less pronounced, and in some cases no changes have been observed (reviewed in Cragg, 1970; Lieberman, 1971). Furthermore, biochemical studies show that the synthesis of a number of proteins is significantly changed following peripheral (Perry and Wilson, 1981; Hall, 1982) but not central (Hall, 1982; Perry et al., 1983), axotomy. Axonal transport studies of cytoskeletal proteins in the DRG cells also demonstrate that the ratio of tubulin "to" neurofilament protein exported into the axon increases after transection of the peripheral axons, but not after transection of the central axons (Oblinger and Lasek, 1985, 1988).

In keeping with these observations, we found that neurofilament protein synthesis in the DRG neurons changed more after transection of their peripheral axons than after transection of their central axons. Nonetheless, transection of the central axons leads to a substantial reduction of neurofilament protein syn- 
CONTROL

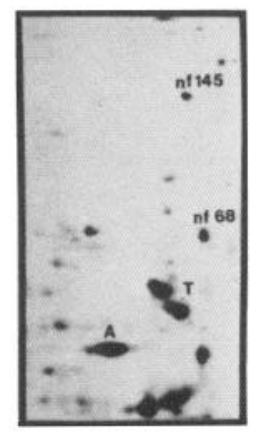

PERIPHERAL CRUSH

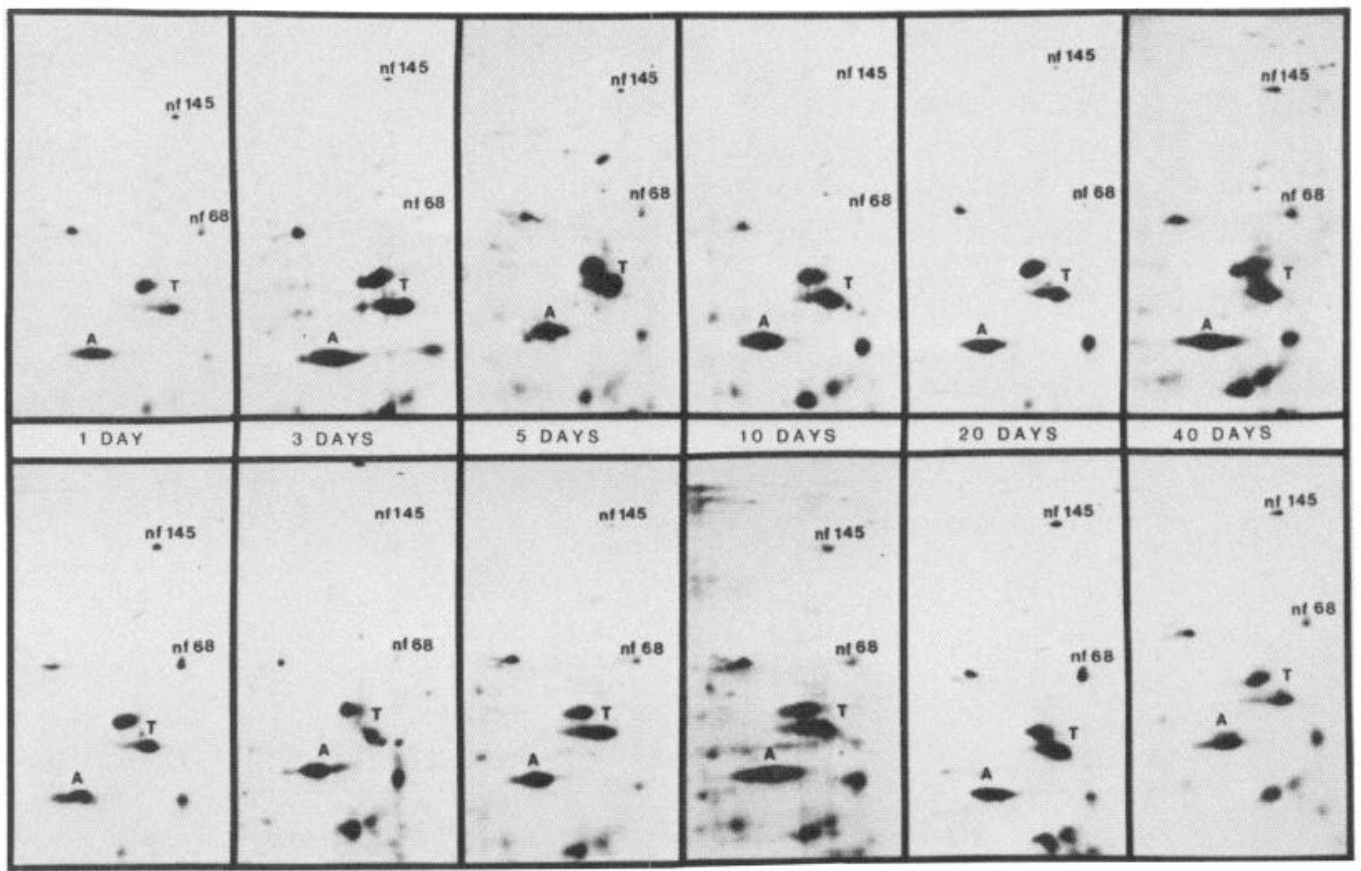

CENTRAL CRUSH

Figure 3. Fluorographs illustrating the time course of protein synthesis changes. At the indicated time intervals after peripheral or central crushes, DRGs were labeled in vitro with ${ }^{35} \mathrm{~S}$-methionine for $1 \mathrm{hr}$ and analyzed by $2 \mathrm{D}$ gel electrophoresis. The fluorographs represent samples in which equal amounts of total radioactivity were analyzed. The cytoskeletal proteins actin $(A)$, tubulin $(T)$, and the 68 and $145 \mathrm{kDa}$ neurofilament proteins $(n f 68, n f 145)$ are indicated. The neurofilament proteins are clearly decreased 3-20 d following a peripheral crush, and 3-10 d following a central crush.

thesis. At $10 \mathrm{~d}$ after central transection, when the effects of transection were greatest, the amount of radiolabeled NF68 protein was reduced to $37 \%$ of that in the contralateral controls. Thus, cutting either the central or peripheral axon can affect cytoskeletal protein synthesis in the cell body of DRG neurons. Moreover, the changes produced by transecting the peripheral axon are in the same direction as those produced by transecting the central axon, but are quantitatively greater for the peripheral axon than for the central axon.

\section{Neurofilament synthesis, neurofilament number, axon diameter, and rapidly conducting neural circuits}

Neurofilaments function chiefly as architectural elements that operate by displacing volume within the neuron and thereby increasing the volume of the neuron (Lasek et al., 1983, 1985; Lasek, 1988; Price et al., 1988). Specifically, neurofilament proteins are assembled into neurofilaments in the nerve cell body, and are then transported into the axon, where they contribute to the radial dimensions of the axon. DRG cells that synthesize large amounts of neurofilament proteins have large numbers of neurofilaments in their cell bodies and axons, and the diameters of their cell bodies and axons are larger than those of DRG cells that synthesize little, if any, neurofilament protein (Hoffman et al., 1987). The diameter of an axon directly affects its conduction velocity, and DRG cells with large amounts of neurofilaments and large-diameter axons have rapidly conducting axons (Lasek, 1988). In general, rapidly conducting axons are components of neural circuits that control locomotion and other somato-muscular movements. Because of the relationships between neu- rofilament synthesis and axon diameter, and between axon diameter and the speed of conduction, understanding the cellular mechanisms that regulate neurofilament synthesis contributes to the understanding of the mechanisms that produce rapidly conducting neural circuits (Lasek, 1988).

\section{Events at the axon tip affect neurofilament protein synthesis in the nerve cell body}

How is neurofilament synthesis regulated? Studies of early neural development show that neurofilament proteins first appear in the embryonic neuroblasts. Furthermore, the expression of the neurofilament genes may be one of the earliest hallmarks of nerve cell differentiation (Sechrist, 1969; Tapscott et al., 1981). Initially, the neurofilaments are expressed at a relatively low or basal level in the young embryonic neuron. Later, when the axon makes synaptic contacts with target neurons, neurofilament protein synthesis increases markedly. For example, in the rat optic system, neurofilaments increase in number at postnatal day 10 (Pachter and Liem, 1984), and this coincides with the period (postnatal days 10-12) when most retinotectal and retinogeniculate synapses are formed (Karlsson, 1967; Lund and Lund, 1972). Furthermore, Pannesse (1963) found that if the size of the peripheral fields innervated by DRG cells increased, then the DRG cells would have more neurofilaments in their cell bodies. Presumably, when these axons branched more and innervated more peripheral target cells, neurofilament protein synthesis was increased. These observations suggest that neurofilament protein synthesis is affected by interactions between the tip of the axon and its target cells. 

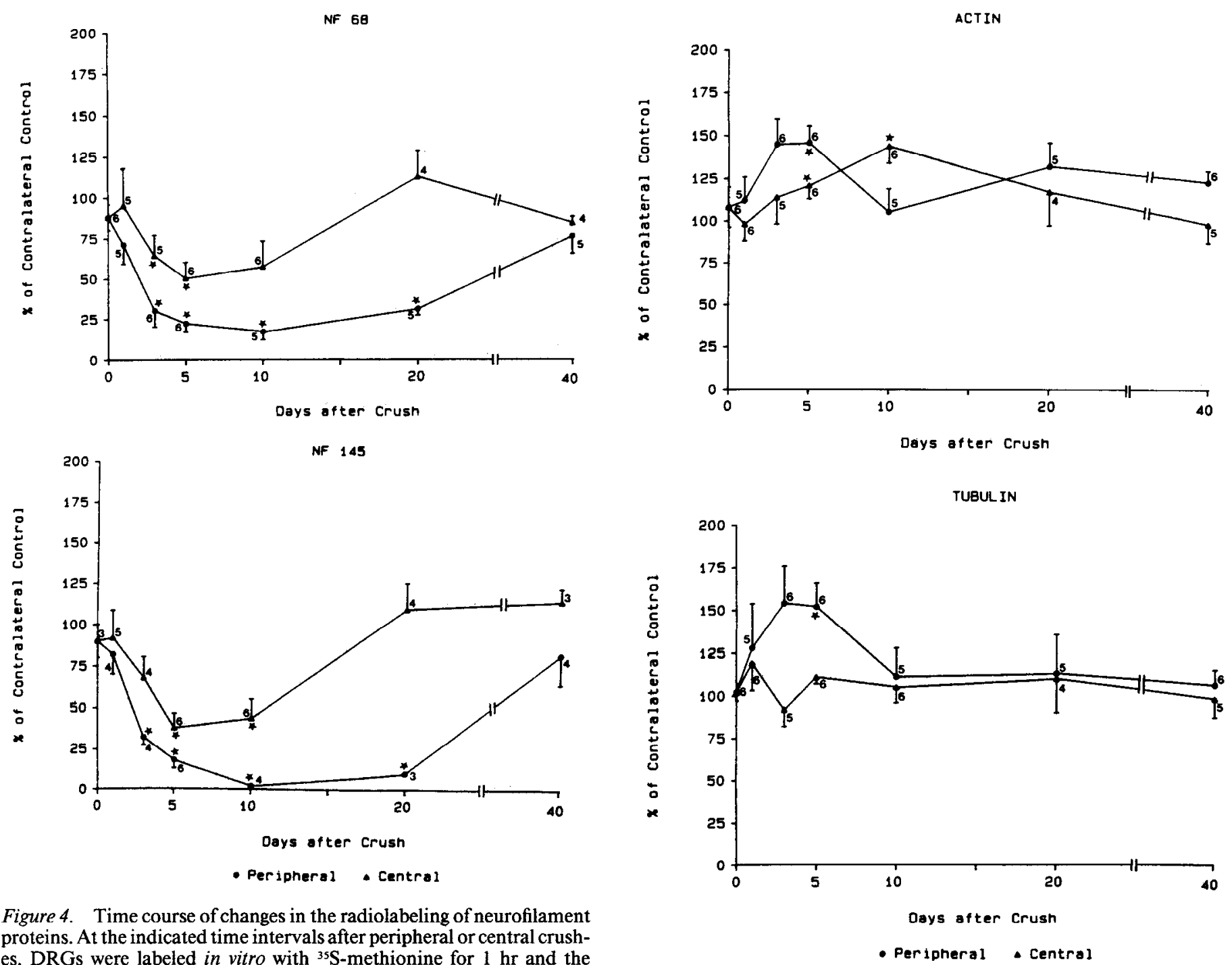

Figure 4. Time course of changes in the radiolabeling of neurofilament proteins. At the indicated time intervals after peripheral or central crushes, DRGs were labeled in vitro with ${ }^{35} \mathrm{~S}$-methionine for $1 \mathrm{hr}$ and the relative levels of the neurofilament proteins were determined by quantification of labeled proteins isolated after 2D gel electrophoresis. Experimental samples were evaluated as a percentage of contralateral control, and significant differences were determined by Student's paired $t$ test. SEMs are also indicated. Stars indicate significant differences $(p<$ $0.05)$. Numbers indicate total animals analyzed at each time point.

This hypothesis is supported by the studies of Hoffman and his colleagues $(1985,1987)$, who have analyzed the effects of separating the neuron from its target cells on neurofilament number and neurofilament mRNA levels. In their studies of mature neurons that have high levels of neurofilament synthesis, they found that if the axon was cut, the amount of neurofilament mRNA decreased in the nerve cell body (Hoffman et al., 1987) and the amount of neurofilament protein and the number of neurofilaments transported into the axon decreased (Hoffman and Lasek, 1980; Hoffman et al., 1985). Furthermore, when these axons regenerated and restored contact with their peripheral target cells, the amount of neurofilament mRNA and the number of neurofilaments transported into the axons increased and returned to the pretransection steady-state levels (Hoffman et al., 1985, 1987). However, if the cut axons were prevented from regenerating, so that the axons could not restore contact with their target cells, the number of neurofilaments transported into the axons and, presumably, the amounts of neurofilament

Figure 5. Time course of changes in the levels of radiolabeled actin and tubulin. At the indicated time intervals after peripheral or central crushes, DRGs were labeled in witro with ${ }^{35} \mathrm{~S}$-methionine for $1 \mathrm{hr}$ and the relative levels of actin and tubulin were determined after quantification of labeled proteins isolated by $2 \mathrm{D}$ gel electrophoresis. Experimental samples were cvaluated as a percentage of their contralateral control, and significant differences were determined by Student's paired $t$ test. SEMs are also indicated. Stars indicate significant differences $(p<$ 0.05). Numbers indicate total animals used at each time point.

protein synthesis did not return to the pretransection steadystate level, but rather remained at the low levels that were produced by cutting the axons (Hoffman et al., 1985). On the basis of these observations, Hoffman et al. (1987) have proposed that interactions between the axon tip and target cells affect the retrograde transport of regulatory factors from the axon tip to the cell body, and that these factors regulate neurofilament protein synthesis at the level of neurofilament mRNA synthesis or processing.

Neurofilament protein synthesis in DRG cells is affected by interactions between the axon tip and cells that stop axonal elongation

Our results support this model for the regulation of neurofilament protein synthesis. Specifically, we found that neurofila- 
ment protein synthesis decreased dramatically when either the central or peripheral axon of the DRG cell is cut. Furthermore, we found that neurofilament protein synthesis increased when the cut axons regenerated and then made contact with cells that stopped them from elongating. The peripheral axons begin to reconnect with their target cells between 21 and $35 \mathrm{~d}$ after transection. [These axons regenerate at $4 \mathrm{~mm} / \mathrm{d}$ (Wujek and Lasek, 1983), and the distance from the transection site to the peripheral target cells is $8.5-15 \mathrm{~cm}$.] Analyses with the pinch test confirmed that sensory innervation of the foot was present in some animals at $40 \mathrm{~d}$, but not at $20 \mathrm{~d}$, after cutting the peripheral axons (unpublished observations). During the period when the peripheral axons reconnected with their target cells (20 and 40 $\mathrm{d}$ after transection), we found that neurofilament protein synthesis increased markedly.

Neurofilament protein synthesis also increased in the DRG cells when the cut central axons regenerated through the dorsal root to the spinal cord. In our experiments, the distance between the spinal cord and the site where the dorsal root was crushed was $2.0-3.3 \mathrm{~cm}$. At this distance, and with a regeneration rate of $2 \mathrm{~mm} / \mathrm{d}$ (Wujek and Lasek, 1983), the central axons reached the spinal cord entry zone at $10-15 \mathrm{~d}$ following transection. When the axons reach the spinal cord, many of them stop elongating and form stationary contacts on astrocytes at the dorsal root entry zone (Liuzzi and Lasek, 1987). Our results indicate that neurofilament protein synthesis increases markedly during the period between 10 and $20 \mathrm{~d}$, when the axons contact the astrocytes and stop elongating. Apparently, neurofilament protein synthesis in the DRG neurons increases when their central axons form axoglial junctions on astrocytes.

This observation suggests that contact between the DRG axons and their normal synaptic targets is not required to elevate the amount of neurofilament protein synthesis in these neurons. Instead, astrocytes that can stop the axon from elongating may be sufficient to stimulate the mechanisms that increase neurofilament protein synthesis. Ultrastructural analyses of the axoglial terminals that the central axons form on astrocytes show that these terminals are similar to presynaptic terminals on neurons (Liuzzi and Lasek, 1987). Notably, these terminals do not contain an excess of cytoskeletal elements or membranous organelles. On the basis of these and other observations, Liuzzi and Lasek (1987) have proposed that astrocytes in the spinal cord of adult rats can stop axonal elongation by activating the "physiological stop pathway"; this pathway normally operates at the axon tip when that tip makes synaptic contact with a target neuron. Apparently, the astrocytes activate proteolytic mechanisms that remove excess axonally transported elements that are continually carried to the axon tip by fast and slow transport. The activation of these mechanisms locally at the axon tip may provide a cue that affects the level of neurofilament protein synthesis in the cell body. For example, changes in the rate of removal of anterogradely transported elements from the axon tip may change the amount or character of retrogradely transported elements that are returned from the axon tip to the cell body (Lasek and Katz, 1987).

\section{Conclusions}

Neurofilament protein synthesis in DRG cells and other large neurons is stimulated by retrogradely transported factors from axon tips that have made stationary axon terminals on cells that stop the axon from elongating. In DRG neurons, these factors are transported to the cell body from the tips of both the pe- ripheral and central axons, and, at steady state, the amounts of these retrograde factors are apparently greater for the peripheral than for the central axon. This difference may be due largely to intrinsic differences in the amounts of material transported in the peripheral and central axons. For example, the amount of membranous elements (fast componcnt) that are anterogradely transported from DRG cell bodies to their peripheral axon tips is larger than that transported to their central axon tips (Lasek, 1968; Ochs, 1972). At the axon tips, these anterograde membranous elements are converted into retrograde membranous elements, which are then returned to the cell body by retrograde transport (Lasek and Katz, 1987). Presumably, the amount of retrograde membranous elements returned from the axon tip is proportional to the amount of anterograde membranous elements supplied to the axon tip. These observations suggest that more retrograde membranous elements return to the DRG cell body from its peripheral axon tips than from its central axon tips. Through this pathway of anterograde transport, anterograde-to-retrograde conversion at the axon tip, and retrograde transport, the amount of anterograde elements that are supplied to the axons of DRG cells may determine the amount of certain regulatory factors that return from the axon tip to influence neurofilament protein synthesis in the nerve cell body.

\section{References}

Bohlem, P., S. Stein, W. Dairman, and S. Uderfriend (1973) Fluorometric assay of proteins in the nanogram range. Arch. Biochem. Biophys. 155: 213-220.

Bonner, W. M., and R. A. Laskey (1974) A film detection method for tritium-labelled proteins and nucleic acids in polyacrylamide gels. Eur. J. Biochem. 46: 83-88.

Cragg, B. C. (1970) What is the signal for chromatolysis? Brain Res. 23: $1-21$.

Giulian, D., H. Des Ruisseaux, and D. Cowburn (1980) Biosynthesis and intraaxonal transport of proteins during neuronal regeneration. J. Biol. Chem. 255: 6494-6501.

Greenberg, S. G. (1986) Changes in cytoskeletal protein synthesis during axonal regencration. Ph.D. thesis, Case Western Reserve University, Cleveland, $\mathrm{OH}$.

Hall, M. E. (1982) Changes in synthesis of specific proteins in axotomized dorsal root ganglia. Exp. Neurol. 76: 83-93.

Heacock, A. M., and B. W. Agranoff (1976) Enhanced labeling of a retinal protein during regeneration of optic nerve in goldfish. Proc. Natl. Acad. Sci. USA 73: 828-832.

Hoffman, P. N., and R. J. Lasek (1980) Axonal transport of the cytoskeleton in regenerating motor neurons: Constancy and change. Brain Res. 202: 347-353.

Hoffman, P. N., J. W. Griffin, and D. L. Price (1984) Control of axon caliber by neurofilament transport. J. Cell Biol. 99: 705-714.

Hoffman, P. N., G. W. Thompson, J. W. Griffin, and D. L. Price (1985) Changes in neurofilament transport coincide temporally with alteration in the caliber of axons in regenerating motor fibers. J. Cell Biol. 101: 1332-1340.

Hoffman, P. N., D. W. Cleveland, J. W. Griffin, P. W. Landes, N. J. Cowan, and D. L. Price (1987) Neurofilament gene expression: A major determinant of axonal caliber. Proc. Natl. Acad. Sci. USA 84: 3472-3476.

Karlsson, U. (1967) Three-dimensional studies of neurons in the lateral geniculate nucleus of the rat. III. Specialized neuronal contacts in the neuropil. J. Ultrastruct. Res. 17: 137-157.

Lasek, R. J. (1968) Axoplasmic transport in cat dorsal root ganglion cells: As studied with $\left({ }^{3} \mathrm{H}\right)$-leucine. Brain Res. 7: 360-677.

Lasek, R. J. (1988) Studying the intrinsic determinants of neuronal form and function. In Intrinsic Determinants of Neuronal Form and Function, R. J. Lasek and M. M. Black, eds., pp. 3-58, Liss, New York.

Lasek, R. J., and M. J. Katz (1987) Mechanisms at the axon tip regulate metabolic processes critical to axonal elongation. Prog. Brain Res. 71: 49-60.

Lasek, R. J., M. M. Oblinger, and P. F. Drake (1983) Molecular biology of neuronal geometry: Expression of neurofilament genes influences 
axonal diameter. Cold Spring Harbor Symp. Quant. Biol. 46: 731744.

Lasek, R. J., L. Phillips, M. J. Katz, and L. Autilio-Gambetti (1985) Function and evolution of neurofilament proteins. In Intermediate Filaments, E. Wang, D. Fishman, R. K. H. Liem, and T. T. Sun, eds. pp. 462-478, Ann. N. Y. Acad. Sci. 455.

Laskey, R. A., and A. D. Mills (1975) Quantitative film detection of ${ }^{3} \mathrm{H}$ and ${ }^{14} \mathrm{C}$ in polyacrylamide gels by fluorography. Eur. J. Biochem. 56: $335-341$

Licbcrman, A. R. (1971) The axon reaction. A review of the principal features of perikaryal responses to axonal injury. Int. Rev. Neurobiol. 14: 49-124.

Luizzi, F., and R. J. Lasek (1987) Astrocytes in mammalian spinal cord block axonal regeneration by activating the physiological stop pathway. Science 237: 642-645.

Lund, R. D., and J. S. Lund (1972) Development of synaptic patterns in the superior colliculus of the rat. Brain Res. 42: 1-20.

Neumann, D., T. Scherson, I. Ginzburg, U. Z. Littauer, and M. Schwartz (1983) Regulation of mRNA levels for microtubule proteins during nerve regeneration. FEBS Lett. 162: 270.

Oblinger, M. M., and R. J. Lasek (1985) Selective regulation of two cytoskeletal networks in dorsal root ganglion cells. In Neurobiology: Molecular Approaches to Understanding Neuronal Function and Development, pp. 135-143, Liss, New York.

Oblinger, M. M., and R. J. Lasek (1988) Axotomy-induced alterations in the synthesis and transport of neurofilaments and microtubules in dorsal root ganglion cells. J. Neurosci. 8: 1747-1758.

Ochs, S. (1972) Rate of fast axoplasmic transport in mammalian nerve fibers. J. Physiol. (Lond.) 227: 627-645.

O'Farrell, P. H. (1975) High resolution two-dimensional electrophoresis of proteins. J. Biol. Chem. 250: 4007-4021.

Pachter, J. S., and R. K. H. Liem (1984) The differential appearance of neurofilament triplet polypeptides in developing rat optic nerve. Dev. Biol. 103: 200-210.
Pannesse, E. (1963) Investigations of the ultrastructural changes of the spinal ganglion neurons in the course of axon regeneration and cell hypertrophy. II. Changes during cell hypertrophy and comparison between the ultrastructure of nerve cells of the same type under different functional conditions. Z. Zellforsch. Mikrosh. Anat. 61: 561586.

Perry, G. W., and D. L. Wilson (1981) Protein synthesis and axonal transnort during nerve regeneration. J. Neurochem. 37: 1203-1217.

Perry, G. W., S. R. Krayanek, and D. L. Wilson (1983) Protein synthesis and fast axonal transport during regeneration of dorsal roots. J. Neurochem. 40: 1590-1598.

Price, R. L., P. Paggi, R. J. Lasek, and M. J. Katz (1988) Neurofilaments are spaced randomly in the radial dimension of axons. J. Neurocytol. (in press).

Quesada, M. H., D. B. Millar, and R. Smejkal (1986) Tubulin synthesis in the regenerating rat superior cervical ganglion: A biphasic response. J. Neurobiol. 17: 77-82.

Schlesinger, M. M., M. Ashburner, and A. Tissieres (eds.) (1982) Heat Schock from Bacteria to Man, Cold Spring Harbor Laboratory, Cold Spring Harbor, NY.

Sechrist, J. W. (1969) Neurocytogenesis. I. Neurofibrils, neurofilaments and the final mitotic cycle. Am. J. Anat. 124: 117-134.

Shaw, G., M. Osborn, and K. Weber (1981) Arrangement of neurofilaments, microtubules and microfilament-associated proteins in cultured dorsal root ganglion cells. Eur. J. Cell. Biol. 24: 20-27.

Tapscott, S. J., G. S. Bennett, Y. Toyama, F. Kleinbart, and H. Holzer (1981) Intermediate filament proteins in the developing chick spinal cord. Dev. Biol. 86: 40-54.

Wujek, J. R., and R. J. Lasek (1983) Correlation of axonal regeneration and slow component $b$ in two branches of a single axon J. Neurosci. 3: 243-251. 